\title{
Falsely Elevated Serum Testosterone Levels in a Young Adult Female with Polycystic Ovarian Syndrome (PCOS) and Left Adrenal Adenoma
}

\author{
Yin Chian Kon ${ }^{1}$ and Robert Hawkins ${ }^{2}$ \\ ${ }^{1}$ Department of Endocrinology, Tan Tock Seng Hospital, Singapore \\ ${ }^{2}$ Department of Laboratory Medicine, Tan Tock Seng Hospital, Singapore
}

\begin{abstract}
Serum testosterone immunoassay interference may cause falsely high results. We report a case of 20 -year-old female with PCOS whose initial serum testosterone levels were more than $10 \mathrm{nM}$. Further imaging revealed a left adrenal adenoma. During an attempt at bilateral adrenal-ovarian venous sampling at another institution, her peripheral serum total testosterone levels on a different assay platform were surprisingly normal. Subsequently, simultaneous samples performed on three different assay platforms confirmed the presence of assay interference from the originating institution.
\end{abstract}

Key words: testosterone immunoassay interference

\section{INTRODUCTION}

Female serum testosterone levels are about one order of magnitude lower than male levels. Thus they are often "read" on a less reproducible part of the standard curve. Laboratories that perform routine measurements of serum total testosterone in clinical samples generally utilize automated direct immunoassays, i.e., without both a prior extraction step to remove conjugated steroids followed by chromatography of the unconjugated steroids. ${ }^{1}$ Elimination of conjugated steroids, which include sulfated and glucoronidated compounds, is important, since they are present in relatively high concentrations compared to unconjugated steroids. ${ }^{2}$ Direct immunoassays may generate falsely high results due to matrix effects in serum samples, and interference by both circulating conjugated e.g., androsterone sulfate, as well as unconjugated e.g., androstenedione, metabolites of testosterone. ${ }^{2}$ This case highlights the importance of excluding testosterone immunoassay interference when the degree of elevation of serum testosterone is discordant with the clinical picture.

\section{CASE}

A 20-year-old female was referred in January 2012 for secondary amenorrhoea. Her last menses was 6 months ago. Her menses, beginning at 9 years of age, were monthly and regular until age 17 years, when they became less frequent, once every 2 months or longer. In June 2011, her menses stopped completely. She gave a history of being treated for pubertal acne, which had resulted in some mild facial scarring at 17 years of age. Over the last 2

e-ISSN 2308-118X

Printed in the Philippines

Copyright (C) 2013 by the JAFES

Received September 7, 2013. Accepted October 9, 2013. years, her weight had increased from $64 \mathrm{~kg}$ to $69 \mathrm{~kg}$. There was no change in voice, hair loss, visual disturbance, galactorrhoea nor headache. There was no history of recreational drug, health supplement nor over-the-counter medication intake. Physical examination revealed weight $69 \mathrm{~kg}$, height $158 \mathrm{~cm}$, BMI $27.7 \mathrm{~kg} / \mathrm{m} 2, \mathrm{BP} 133 / 68 \mathrm{mmHg}$, heart rate $74 / \mathrm{min}$ regular. She did not appear Cushingoid, nor was there skin atrophy, proximal weakness nor easy bruising to suggest Cushing's syndrome. She was mildly hirsute, her modified Ferimann-Galway score being 7 . Acanthosis nigricans and skin tags were absent. Abdominal examination was unremarkable. Although her clitoris was prominent, there was no cliteromegaly. Transabdominal pelvic ultrasound scan showed uterus length $7.9 \mathrm{~cm} \times$ width $4.7 \mathrm{~cm} \times$ transverse diameter $4.0 \mathrm{~cm}$ and endometrial thickness $6 \mathrm{~mm}$. Both ovaries were enlarged: right ovary length $3.8 \mathrm{~cm} \times$ width $3.2 \mathrm{~cm} \times$ transverse diameter $1.8 \mathrm{~cm}$, volume $11.4 \mathrm{ml}$. Left ovary length $4.3 \mathrm{~cm}$ $\mathrm{x}$ width $3.6 \mathrm{~cm}$ x transverse diameter $1.9 \mathrm{~cm}$, volume 15.3 $\mathrm{ml}$. Several small immature follicles were noted in both ovaries, compatible with polycystic ovarian morphology.

Of concern, her serum testosterone level was markedly elevated at $11.0 \mathrm{nM}$ (0.5-3.8). Other serum hormonal parameters were: prolactin $42.8 \mathrm{ug} / \mathrm{L}$ (7-33), E2 44 pM, LH $4.16 \mathrm{IU} / \mathrm{L}, \mathrm{FSH} 3.4 \mathrm{IU} / \mathrm{L}$, progesterone $0.71 \mathrm{nM}$ and $\mathrm{TSH}$ $0.94 \mathrm{mIU} / \mathrm{L}(0.45-4.5)$. Oral glucose tolerance test was normal and excluded the presence of hyperinsulinism, but her hyperandrogenemia was apparently persistent (Table 1). Her serum sex hormone binding globulin (SHBG) level was suppressed, consistent with hyperandrogenism. Cushing's syndrome was unequivocally excluded (Table

Corresponding author: Yin Chian Kon, MD

Department of Endocrinology

Tan Tock Seng Hospital

11 Jalan Tan Tock Seng

Singapore 308433

Tel. No.: 65-81263173

Fax No.: 65-63573087

E-mail:Winston_Kon@ttsh.com.sg 
2). However, her serum testosterone levels failed to suppress by more than $40 \%$ on LDDST (low dose dexamethasone suppression test), suggesting the presence of an androgen secreting tumour. ${ }^{3}$ Accordingly, computer tomography of her adrenal glands was performed, demonstrating a nodular configuration in the lateral limb of her left adrenal gland, Hounsfield units 18-99-49, with $62 \%$ washout suggestive of a left adrenal adenoma; her right adrenal gland and the rest of her abdomen were normal (Fig 1).

She was referred to another institution for bilateral adrenal-ovarian venous sampling under ACTH stimulation, looking in particular for a left adrenalperipheral venous testosterone gradient. To our surprise, her peripheral serum total testosterone levels, measured on a different assay platform, returned as normal (Fig 2). We realized for the first time that there might be presence of assay interference. Consequently, the results of simultaneous serum samples assayed on three different platforms confirmed the presence of assay interference from the originating institution (Table 3). By that time, about one year after she initially presented, her FerrimanGalway score had improved to 4 , as she had reduced her weight to $60 \mathrm{~kg}$, body mass index $24 \mathrm{~kg} / \mathrm{m} 2$, with lifestyle changes. She remains under surveillance for her small left adrenal nodule.

\begin{tabular}{|c|c|c|c|c|}
\hline OGTT & Units & Ref Range & $0 \mathrm{~min}$ & $120 \mathrm{~min}$ \\
\hline Glucose & $\mathrm{mM}$ & & 5.1 & 6.1 \\
\hline Insulin & $\mathrm{mlU} / \mathrm{L}$ & & $\begin{array}{c}8.1 \\
(1-30)\end{array}$ & $\begin{array}{l}52.5 \\
(<80)\end{array}$ \\
\hline C-peptide & ug/L & $0.1-3.2$ & 1.7 & \\
\hline $\begin{array}{l}\text { Total Testosterone } \\
\text { (Abbott Architect) }\end{array}$ & $\mathrm{nM}$ & $0.5-3.8$ & 11.4 & \\
\hline $\begin{array}{l}\text { Sex Hormone } \\
\text { Binding Globulin }\end{array}$ & $\mathrm{nM}$ & $20-122$ & 17 & \\
\hline Free Androgen Index & $\%$ & $<4$ & 67 & \\
\hline DHEAS & $\mathrm{uM}$ & $1.1-11.8$ & 7.9 & \\
\hline 17-OH Progesterone & $\mathrm{nM}$ & & 4.8 & \\
\hline
\end{tabular}

Table 2. Tests to exclude Cushing's syndrome show nonsuppression of serum total testosterone levels on Low dose dexamethasone suppressions

\begin{tabular}{|c|c|c|c|c|}
\hline & Units & Ref Range & Result & \\
\hline $\begin{array}{l}1 \text { mg ONDST } \\
8 \text { am Cortisol }\end{array}$ & $\mathrm{nM}$ & $<50$ & 29 & \\
\hline 24hUFC & nmoles/d & $59-413$ & 119 & \\
\hline \multirow[t]{3}{*}{$\begin{array}{r}\text { 24Hr Urine Vol } \\
\text { Low Do }\end{array}$} & $\begin{array}{c}\text { mls } \\
\text { Dexameth }\end{array}$ & $\begin{array}{l}700-2000 \\
\text { sone Suppre }\end{array}$ & $\begin{array}{c}1242 \\
\text { sion Test }\end{array}$ & \\
\hline & & & Baseline & Post \\
\hline & Units & $\begin{array}{c}\text { Ref } \\
\text { Range }\end{array}$ & $\begin{array}{c}26.05 .12 \\
(8 \mathrm{am})\end{array}$ & $\begin{array}{c}28.05 .12 \\
(8 \mathrm{am})\end{array}$ \\
\hline $\begin{array}{l}\text { Total Testoserone } \\
\text { (Abbott Architect) }\end{array}$ & $\mathrm{nM}$ & $0.5-3.8$ & 10.6 & 8.0 \\
\hline SHBG & $\mathrm{nM}$ & $20-122$ & 21 & 21 \\
\hline Androstenedione & $\mathrm{nM}$ & 2-9.2 & 4.9 & 2.2 \\
\hline DHEAS & $\mathrm{nM}$ & $1.1-11.8$ & 5.5 & 2.2 \\
\hline 170HP & $\mathrm{nM}$ & $\begin{array}{l}F: 0.6-5.5 \\
\text { L: } 0.7-14.2\end{array}$ & 7.8 & - \\
\hline FSH & IU/L & & 5.9 & 4.5 \\
\hline LH & IU/L & & 16.34 & 14.96 \\
\hline АСТH & $\mathrm{ng} / \mathrm{L}$ & $10-60$ & 38.2 & 2.0 \\
\hline Cortisol & $\mathrm{nM}$ & $123-626$ & 554 & $<11$ \\
\hline Prolactin & ug/L & 7-33 & 14.36 & \\
\hline
\end{tabular}

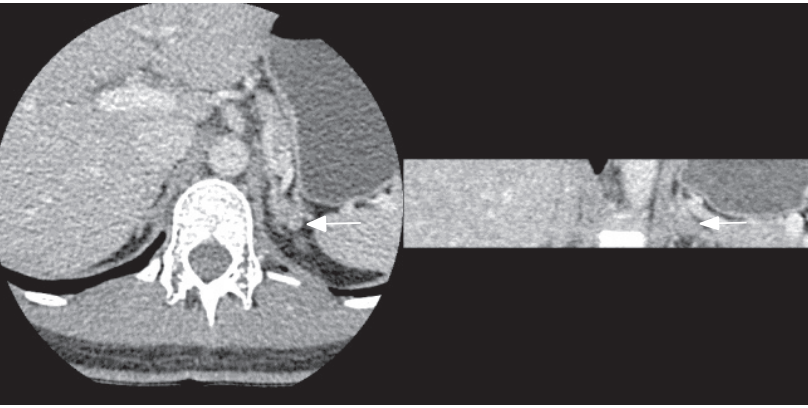

Figure 1. CT Adrenals: right adrenal gland unremarkable; left adrenal gland body and lateral limb has nodular configuration (white arrow), Hounsfield units 18-99-49, $62 \%$ washout suggestive of adrenal adenoma

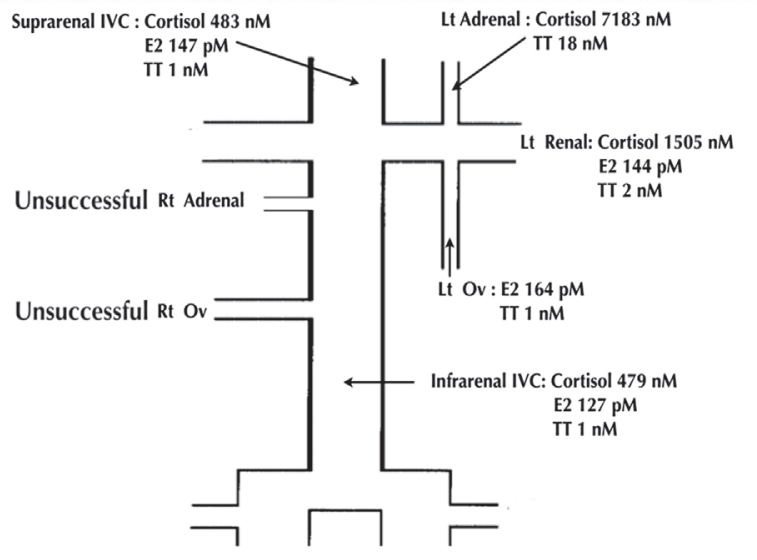

Figure 2. Left Adrenal-Ovarian Venous Sampling under ACTH Stimulation (IV ACTH $250 \mathrm{mcg}$ in $500 \mathrm{ml}$ normal saline over $4 \mathrm{hrs}$ ) reveals normal peripheral serum total testosterone levels (Beckman Coulter Dxl 800).

\section{DISCUSSION}

Polycystic ovarian syndrome (PCOS), the commonest cause of menstrual and reproductive disturbance in women of reproductive age, classically has a perimenarcheal onset. It may also present postmenarche in the predisposed patient who gains weight, as in our case, ${ }^{4}$ PCOS may occasionally present with severe clinical hyperandrogenism, making it difficult to distinguish from tumoral causes of hyperandrogenism. Our patient fulfilled both NIH and Rotterdam diagnostic criteria for PCOS, as she presented with oligoamenorrhoea, mild hirsutism and bilateral enlarged ovaries. Both Cushing's syndrome and 21-hydroxylase enzyme deficiency were excluded. Her serum SHBG level was suppressed, consistent with the presence of hyperandrogenism. Her persistently high serum LH compared to FSH level is consistent with the diagnosis of PCOS associated with relatively lean body adiposity. ${ }^{5}$

Virilizing tumours most commonly arise in the ovary, less commonly, adrenocortical carcinomas present with mixed Cushing's syndrome plus virilization. In adults, adrenal tumours that exclusively secrete androgens without excess 


\begin{tabular}{|c|c|c|c|c|c|}
\hline Date & $\begin{array}{c}\text { Total Testosterone } \\
\text { Beckman Coulter DxI } 800\end{array}$ & Estradiol & LH & FSH & DHEAS \\
\hline $\begin{array}{r}03.12 .12 \\
\text { Date }\end{array}$ & $\begin{array}{c}1 \mathrm{nM} \\
\text { Beckman Coulter DxI } 800\end{array}$ & $\begin{array}{c}174 \mathrm{pM} \\
\text { Total Testosterone } \\
\text { Siemens Centaur }\end{array}$ & $\begin{array}{c}15 \mathrm{IU} / \mathrm{L} \\
\text { Abbott Architect }\end{array}$ & $\begin{array}{c}6 \mathrm{mlU} / \mathrm{L} \\
\text { Androstenedione } \\
6.0 \mathrm{nM} \\
(2-9.2)\end{array}$ & $\begin{array}{c}9.22 \mathrm{nM} \\
\text { SHBG } \\
25 \mathrm{nM} \\
(20-122)\end{array}$ \\
\hline 04.12 .12 & $2 \mathrm{nM}$ & $2.7 \mathrm{nM}$ & $15.7 \mathrm{nM}$ & & \\
\hline
\end{tabular}

cortisol are rare. Typically they are $4 \mathrm{~cm}$ or more and secrete predominantly weak androgen precursors that are converted peripherally to testosterone. ${ }^{6}$ However, adrenal tumours that secrete mainly testosterone have also been described. Ovarian androgen-secreting tumours may be microscopic and difficult to image, whereas adrenal androgen-secreting tumours usually declare themselves on radiologic imaging, being more than $1.5 \mathrm{~cm}$ in size. ${ }^{7}$

In PCOS patients, the severity of hirsutism correlates poorly with serum total testosterone levels. ${ }^{8}$ Presence of virilization or serum total testosterone levels more than twice the upper limit of normal in a female should alert the clinician to the presence of androgen-secreting tumour, however, some cases of PCOS may present with virilization. Moreover, some patients with androgensecreting tumour may present with milder than expected degrees of hyperandrogenism and hyperandrogenemia. In a clinical study of 14 hirsute women with histologically proven adrenal tumours (12 adrenal carcinomas, 2 adrenal adenomas), the mean Ferriman-Galway score was 16, with a range from 8 to $34 .{ }^{9}$ Three patients presented with mild hirsutism, and 5 out of 14 patients had no other features of virilization. Four patients had normal serum dehydroepiandrostenendione sulphate (DHEAS) levels, and in 4 patients, serum total testosterone level was less than twice the upper limit of normal women. ${ }^{9}$ In a more recent retrospective consecutive case series from a single centre, 44 females with androgen-secreting adrenocortical tumours were compared with 102 female controls with non-tumoral androgen excess. The prevalence of hirsutism, acne and oligomenorrhoea was not significantly different between the two groups. ${ }^{10}$ Although the tumour group had significantly higher androgen levels, there was great overlap between the two groups. Notably, a serum total testosterone more than twice the upper normal limit gave a specificity of $100 \%$, but only a low sensitivity of $47 \%$, for diagnosing androgen-secreting adrenocortical tumour. In this study, all tumours were $4 \mathrm{~cm}$ or more in size. ${ }^{10}$

When there is doubt, suppression of elevated serum testosterone levels either with conventional LDDST $^{3}$ or dexamethasone for 5 days $^{9}$ may help to distinguish tumoral (either ovarian or adrenal) from non-tumoral hyperandrogenism. Adults of reproductive age suspected to have tumoral hyperandrogenism should then undergo both adrenal and ovarian imaging to determine if the source is right or left sided, adrenal or ovarian in origin, with a view to curative resection in the first instance. When the results of adrenal and ovarian imaging are equivocal, bilateral adrenal-ovarian venous sampling for testosterone may be considered. However, this radiologic procedure is invasive and technically difficult. Even in expert hands, only $29-45 \%$ of patients are able to have all 4 veins successfully cannulated. ${ }^{11,12}$ The right adrenal and right ovarian veins are particularly difficult to cannulate because of their angled origin direct from the inferior vena cava, anatomic variation and valvular obstruction, especially in nulliparous females. ${ }^{11,12}$

Very few studies have documented basal serum testosterone levels from adrenal veins in normal premenopausal females, let alone under ACTH stimulation. One study documented basal adrenalperipheral venous testosterone gradient to be 2-6 times, with absolute adrenal vein testosterone values generally below 20 nM. $^{13}$ Acute ACTH stimulation increases peripheral serum testosterone about 2 times, mainly via increased adrenal androstenedione and not testosterone secretion. Although our patient showed a left adrenalperipheral venous testosterone gradient of $17 \mathrm{nM}$ (Fig. 2), it was her unexpectedly normal peripheral serum total testosterone values during this procedure that alerted one to suspect assay interference for the first time: the main lesson of this case. We did not subsequently perform organic solvent extraction followed by immunoassay, nor assay by mass spectrometry, as such facilities are not available locally. It is unclear why her results are spuriously elevated in one particular assay platform and not in the other two (Table 3). Intake of exogenous androgenic compounds such as danazol, mifepristone, DHEA supplements or a herbal root aphrodisiac called maca $^{14}$ have been reported to result in falsely high serum testosterone results, but our patient denied any history of health supplement or herbal medicine intake.

\section{CONCLUSION}

Commercial direct immunoassays for measuring female serum testosterone levels may give falsely high results in some samples. This could potentially result in normal women misdiagnosed as having PCOS, or in our case, women with PCOS misdiagnosed as having an androgensecreting tumour. Clinicians must exclude the possibility of serum testosterone immunoassay interference when the degree of elevation of serum testosterone is discordant with the clinical picture. In practice, it is prudent to repeat 
analysis of samples reading more than twice the upper normal limit using alternative assays, using organic solvent extraction before immunoassay, or mass spectrometry, before subjecting patients to further investigation. This will avoid searching for tumoral source of hyperandrogenism when in fact none exists.

\section{References}

1. Kane J, Midddle J, Cawood M. Measurement of serum testosterone in women; what shall we do? Ann Clin Biochem 2007;44:5-15e

2. Stanczyk FZ, Cho MM, Endres DB, et al. Limitations of direct estradiol and testosterone immunoassay kits. Steroids 2003;68:1173-8

3. Kaltsas GA, Isidori AM, Kola BP, et al. The value of low-dose dexamethasone suppression test in the differential diagnosis of hyperandrogenism in women. J Clin Endocrinol Metab 2003;88:263443

4. Futterweit W, Diamanti-Kandarakis E, Azziz R. Clinical features of the polycystic ovarian syndrome. Androgen Excess Disorders in Women, Chapter 14. Humana Press, 2007.

5. Arroyo A, Laughlin GA, Morales AJ, et al. Inappropriate gonadotrophin secretion in polycystic ovary syndrome: influence of adiposity. J Clin Endocrinol Metab 1997;82:3728-33

6. Cordera F, Grant C, van Heerden J, et al. Androgen secreting adrenal tumours. Surgery 2003;134:874-80
7. Pugeat M, Raverot G, Plotton I, et al. Androgen-secreting adrenal and ovarian neoplasms. Androgen Excess Disorders in Women, Chapter 6. Humana Press, 2007.

8. Legro R, Schlaff WD, Diamond MP. Total testosterone assays in women with polycystic ovary syndrome: Precision and correlation with hirsutism. J Clin Endocrinol Metab 2010;95:5305-13

9. Derksen J, Nagesser SK, Meinders AE. The identification of virilizing adrenal tumours in hirsute women. N Eng J Med 1994;331:968-73

10. $d^{\prime}$ Alva CB, Abiven Lepage $G$, Viallon $V$, et al. Sex steroids in androgen-secreting adrenocortical tumours: Clinical and hormonal features in comparison with non-tumoral causes of androgen excess. European Journal of Endocrinology 2008;159:641-7.

11. Kaltsas GA, Mukherjee JJ, Kola B, et al. Is ovarian and adrenal venous catheterization helpful in the investigation of hyperandrogenic women? Clinical Endocrinology 2003;59:34-43

12. Sorensen R, Moltz L, Schwartz U. Technical difficulties of selective venous blood sampling in the differential diagnosis of female hyperandrogenism. Cardiovasc Intervent Radiol 1986;9:75-82

13. Kirschner MA, Jacobs JB. Combined ovarian and adrenal catheterization to determine the site of androgen overproduction in hirsute women. J Clin Endocrinol 1971;33:199-209

14. Srikugan L, Sankaralingam A, McGowan B. First case report of testosterone assay-interference in a female taking maca (Lypedium meyenni). BMJ Case Reports 2011;doi:10.1136/bcr.01.2011.3781

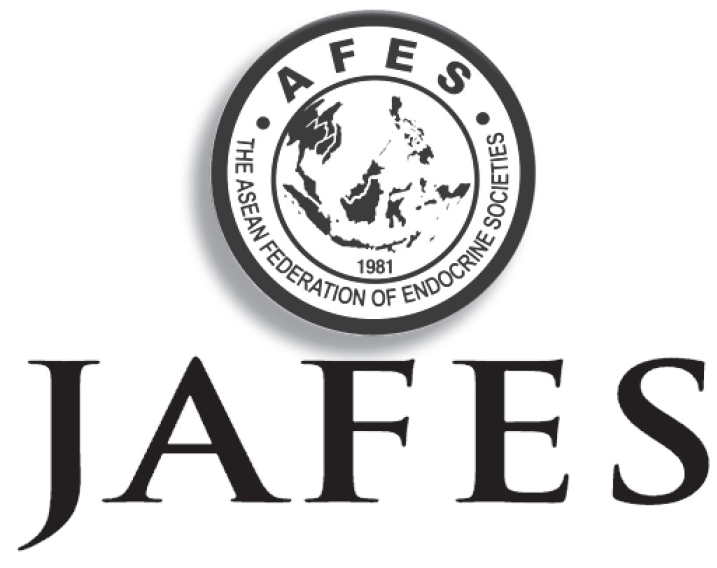

Experience the new JAFES. Visit us at www.ASEAN-endocrinejournal.org. 